\title{
Photography in the planning of health interventions for the elderly
}

\author{
A fotografia no planejamento de intervenções de saúde dirigidas a idosos \\ La fotografía en la planificación de intervenciones de salud dirigidas a ancianos
}

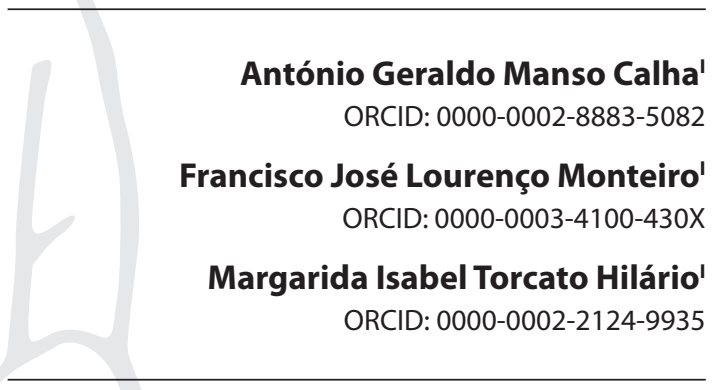

IInstituto Politécnico de Portalegre. Portalegre, Portugal.

How to cite this article:

Calha AGM, Monteiro FJL, Hilário MIT. Photography in the planning of health interventions for the elderly. Rev Bras Enferm. 2019;72(4):940-7. doi: http://dx.doi.org/10.1590/0034-7167-2018-0329

Corresponding Author: António Geraldo Manso Calha E-mail:antoniocalha@hotmail.com

Submission: $05-25-2018$

Approval: 09-09-2018

\section{ABSTRACT}

Objective: To analyze potentialities of the use of photo-elicitation technique as a tool of access to the real needs of the beneficiaries of the intervention of health professionals. For this purpose, the aspects of their quality of life that they considered more relevant were identified with an elderly group. Method: It is a qualitative investigation in which the discourse of the elderly on the changes to their quality of life is encouraged through the use of photographic images. Results: Based on the data obtained, it was possible to identify the aspects of quality of life considered more relevant by the elderly, allowing, therefore, to sustain a later intervention adjusted to the needs and expectations of the elderly. Final considerations: The use of photo-elicitation allowed verifying its potentialities as a strategy to collect significant and relevant information for the planning of interventions in the Health area.

Descriptors: Photography; Narration; Quality of Life; Aged; Nursing.

\section{RESUMO}

Objetivo: Analisar as potencialidades da utilização da técnica da foto-elicitação enquanto instrumento de acesso às reais necessidades dos beneficiários da intervenção dos profissionais de saúde. Com esse propósito, foram identificados, junto a um grupo de idosos, os aspetos da sua qualidade de vida que consideram mais relevantes. Método: Trata-se de uma investigação qualitativa em que o discurso dos idosos sobre as alterações à sua qualidade de vida é estimulado através do recurso a imagens fotográficas. Resultados: Com base nos dados obtidos, foi possível identificar os aspetos da qualidade de vida considerados mais relevantes pelos idosos, permitindo, assim, sustentar uma posterior intervenção ajustada às necessidades e expectativas do idoso. Considerações finais: A experiência de utilização da foto-elicitação permitiu constatar as suas potencialidades enquanto estratégia de recolha de informação significativa e relevante para o planejamento de intervenções na área da Saúde. Descritores: Fotografia; Narração; Qualidade de Vida; Idoso; Enfermagem.

\section{RESUMEN}

Objetivo: Analizar las potencialidades de la utilización de la técnica de la foto-elección como instrumento de acceso a las reales necesidades de los beneficiarios de la intervención de los profesionales de salud. Con ese propósito, se identificaron, junto a un grupo de ancianos, los aspectos de su calidad de vida que consideran más relevantes. Método: Se trata de una investigación cualitativa en la que el discurso de los ancianos sobre las alteraciones a su calidad de vida es estimulado mediante el uso de imágenes fotográficas. Resultados: Con base en los datos obtenidos, fue posible identificar los aspectos de la calidad de vida considerados más relevantes por los ancianos, permitiendo así sostener una posterior intervención ajustada a las necesidades y expectativas del anciano. Consideraciones finales: La experiencia de utilización de la foto-elicitación permitió constatar sus potencialidades como estrategia de recogida de información significativa y relevante para la planificación de intervenciones en el área de la Salud.

Descriptores: Fotografía; Narración; Calidad de Vida; Anciano; Enfermería. 


\section{INTRODUCTION}

From the middle of the twentieth century there was a gradual change in the conception of the meaning of care, accompanied by a change in the models of health professionals, particularly nurses. The questions about the practice of care and what characterizes them give rise to several reflections that seek to clarify the specific domain of care. These reflections led to the development of conceptual and explanatory models of nursing care, as they evidence their attention in caring and try to guide practice, training and research in Nursing, as well as to make nurses more explicit in their interventions ${ }^{(1)}$. In this process of changing the conception of caring it is possible to identify the influence of the Social Sciences as well as of different lines of thought that conceive the human being as a multidimensional being (that influences and is influenced by the environment in which it is integrated).

The purpose of Nursing comes to be seen as an end and not as a means, the care in itself. This emphasis is reflected in the various models of care that, although they differ from one another, have in common the fact that they are centered on the person as a care subject, on a holistic perspective, on the nurse's action and on the relationship between the patient and the patient, valuing the interpersonal relationship and the individuality of each person ${ }^{(2)}$. Since the 1970 s, the concept of care has been affirmed as an idea in Nursing encompassing broad and diverse notions such as the act of assisting, affective involvement, responsibility and the relationship with the other human being ${ }^{(3)}$. The intervention in Nursing meets the individual needs of each subject according to the specificity of each situation and resorting to the mobilization of adequate knowledge, of a theoretical, technical and relational nature, and adapted to the singularity of each situation. Nursing care has as its main concern the person, as a unique and irreplaceable person, the beneficiary of the intervention is not a mere object or number, but is rather a natural person in a given situation, who is given individualized care (even personalized) and whose rights and needs are always respected. Hence, the caregiver is not only concerned with the treatment and/or cure of the disease, but also (and above all) with the satisfaction of the most urgent needs of the sick person.

The concept of caring influences theory, research, practice and teaching in Nursing ${ }^{(4)}$. This assumption implies that the nurse is endowed with the ability to listen and understand the other, recognizing the value of the inner world of the person. It is at the end of the decade of the 70's of the twentieth century that, through the work of Jean Watson, we begin to highlight the value of access to this inner world of subjects through research, reflection and action of the meanings of the person and the process of caring, during health-disease experiences ${ }^{(5)}$. This is what is called nurses' artisan work, which brings together creativity with scientific knowledge ${ }^{(6)}$. The art of caring consists in the ability to gather all the components of a particular situation, to understand them and to work them, shaping them to the situation in question, according to the needs of the person, that is, the nurses, as providers of care, put into practice care in all its complexity and in all its dimensions. Besides, nurses have important and specific resources that make their care delivery unique. These resources include:'primary care' (e.g., hygiene and comfort care, feeding care, mobilization, etc.) that place the nurse in contact with the patient's intimacy;'A continuous presence', which allows nurses to be with the patient and his family at all times, sharing good and bad moments, doubts, expectations and uncertainties, listening to personal stories - hopes and dreams, thoughts and feelings; and 'a world of actions of a more or less technical character', which highlights the scientific and technical aspects of their care. This shows that nurses are 'specialists of small things', far from being a'label' with negative connotation and this is a supreme quality of Nursing. The professionalism of the nurse is measured by the way he values small things, and besides the technical and complex actions he must also have the capacity to go out to the other and to accompany him, to walk with him, to exalt things apparently banal and devoid of sophistication, but that make all the difference to who is taken care of, since it reveals concern and attention on the part of those who take care.

In this sense, caring is not the mere sum of fragmented actions, technical, basic or educational, the depth of care involves the creation of relationships with the person to accompany and walk with $\mathrm{him}^{(6)}$. The spirit of care is not subject exclusively to technical-scientific logic or organizational principles, caring is assumed as a fundamental value, where everything, in its smallest details, forms a coherent whole moved by the same intention: The care to be provided to the person ${ }^{(6)}$.

\section{OBJECTIVE}

To analyze the use of innovative processes that provide nurses with easy access to the real needs of the beneficiaries of the intervention. This article, based on a communication presented at the VI Ibero-American Congress on Qualitative Research ${ }^{(7)}$, aims to be a contribution to the planning of nursing interventions that take into account the counseling of their beneficiaries and the identification of the needs expressed by them. The photographic image and the narrative were used as tools for listening and information gathering. In this case, we sought to identify with a group of elderly users of a Day Center (Centros De Dia are specialized facilities for the elderly, where a group of professionals is dedicated to the prevention, treatment and care of the elderly. The elderly can stay in their homes, spend the evenings and weekends, so there is no total disengagement with their environment of reference, their environment, since they are not in situations of total dependence), the aspects of their quality of life that they consider more relevant. For this, the photo-elicitation technique was used in order to analyze the individual perceptions.

With the use of this technique, we intend to identify the value of the information contained in the details of the narrative built around the photographs presented to the elderly. This valuation of detail is, moreover, one of the components of nursing work, given that it is the little things that contribute to giving meaning to life, to feed hope in the act of caring ${ }^{(6)}$.

\section{METHOD}

\section{Ethical aspects}

The authors guided their conduct by the scrupulous fulfillment of the Code of Ethics of the Instituto Politécnico de Portalegre, which constitutes the formal ethical statement and guiding reference of the actions for all the integral parts of this Institution. Throughout the research, the ethical requirements governing the scientific practice were followed, all participants participated 
voluntarily and were informed in advance of the purpose of the sessions and were given the possibility to abandon the research at any time and without any loss folks.

\section{Theoretical and methodological frameworks}

The use of photography as a research tool in Health is not recent and is a tradition framed in research of a qualitative nature. Research based on the use of photography has revealed its potential as a phenomenological research technique, in particular: I) in the way it allows to uncover the personal and unique experiences of the subjects; II) the way in which one can better understand the other; and III) the way in which it provides the perception of the way of interpretation and subjective construction of reality. Still, little has been the dissemination of photography as a work resource in the different Health areas.

The few studies in the field of Health that use photography are quite heterogeneous as to the nature of the phenomena under study. We find examples of the use of photography to understand the experience of pregnant women in their contact with a maternal and child service at birth ${ }^{(8)}$. Also at the level of observation, evolution and registration of adjacent lesions and tissues, photography has proved to be a useful tool ${ }^{(9)}$. Also, based on the photograph, we analyzed the ways of working of a nursing team and its relationship with patients and other health professionals ${ }^{(10)}$. In another example, using photovoice, we analyze the factors involved in the quality of nursing care for dependent elderly people in home care ${ }^{(11)}$.

The way photography is used, as a working tool, in the different researches, is quite variable. In some studies, researchers give photographic cameras to participants for them to record a certain reality ${ }^{(8,11)}$. In these cases, the hermeneutical value of the photograph is emphasized, being considered as a visual language that carries meaning and can be deciphered and discussed. Thus, images cannot be understood as a mere register of reality, they carry beliefs and values as cultural and social manifestations ${ }^{(8)}$.

In other studies ${ }^{(12)}$, the photographic image is determined a priori by the researchers and used as an encouragement to participants for the production of narratives. In these investigations, photography is used to allow the viewer to assign a meaning and interpretation of the life experience. The aim is to trigger a reflective process so that experience, the existential dimension of living, can be approached and understood through the symbolic and metaphorical associations of individuals.

In the case of this research, in view of its objectives, the preparation of the sessions with the elderly was in line with the concept of quality of life as defined and operationalized by the Whoqol Group of Experts, designated by the World Health Organization ${ }^{(13)}$. From the work of this group resulted a concept of quality of life of subjective appearance and multidimensional nature, framed by the cultural context and value system in which individuals determine not only their goals, expectations, but also their fears and concerns. The breadth and complexity of the concept encompasses dimensions as diverse as physical health, psychological state, social relationships and the surrounding environmental characteristics. Thus, the selection of photographs used in the sessions with the elderly sought to encompass the following domains: Physical, psychological, social relations and environment. For each of the domains of quality of life, a photographic file was produced, for a total of four. Each of the files contained two images depicting antagonistic realities related to the experience of old age in each domain.

At the physical level, it was sought to understand how in the discourse of the elderly spontaneously emerged themes related to the greater or lesser capacity to perform activities of daily living, pain and discomfort or fatigue and energy. In this sense, in the file related to the physical domain, there was a photo of elderly people performing physical exercise and a photo of an elderly couple pulling a shopping cart, with difficulties of locomotion, using auxiliary means of walking. In the psychological domain, they included on the record two photographs depicting an elderly man laughing and an elderly man with a sad face. In this area we have tried to evoke issues such as sadness, self-esteem or negative and positive feelings. In the file on social relations, the aim was to approach personal relationships, isolation and social support, through a photograph of elderly people who live together socially and a photograph that portrays an elderly only. Concerning the domain related to the environment, it was tried to check in the discourse of the participants' references to their sense of physical security, the environment of the home and the financial resources.

\section{Type of study}

This is a qualitative study, with a methodological emphasis on photo-elicitation. The data were collected in group discussion sessions and data analysis was performed from the content analysis.

\section{Methodological procedures}

The purpose of the four tokens used in the group sessions with the elderly was to encourage the participants with elements that evoked their individual frame of reference, respecting their language and their mental characteristics. The researcher responsible for the field work carried out three group sessions with the 12 elderly people.

\section{Study setting}

All sessions were held in the Day Center. In each session, the elderly were asked to observe each of the four tokens and individually to choose the one that best illustrates the old age. After the choice, each elder was asked to justify to the group his/her choice, simultaneously allowing the debate about the choices and justification of the same. Each session had an approximate duration of one hour and was very well received by the elderly participants.

\section{Data source}

The data source consisted of elderly people attending a Day Center in the district of Portalegre. For the selection of the participants, characterized in Table 1, the following inclusion criteria were adopted: Being older than 65, attending the Day Center for more than six months. We excluded the elderly with cognitive deficits, measured through the responses to the Minimal Mental State Examination. 
Table 1 - Characterization of the elderly group

\begin{tabular}{ccccc}
\hline Elderly & Sex & Age & Marital Status & Family Unit \\
\hline A & Female & 68 years & Single & Lives alone; has no children; has 2 brothers \\
B & Female & 84 years & Widow & Lives alone; has 2 children \\
C & Female & 81 years & Widow & Lives with her son and daughter-in-law; has 2 children \\
D & Female & 93 years & Widow & Lives alone; has 2 children \\
E & Female & 76 years & Widow & Lives alone; has 5 children \\
F & Male & 88 years & Married & Lives with his wife; has 1 child \\
G & Male & 74 years & Married & Lives alone; has 2 children \\
H & Male & 84 years & Single & Lives alone; has no children \\
I & Male & 69 years & Divorced & Lives alone; has 1 child \\
J & Female & 82 years & Widow & Lives alone; has 2 children \\
K & Female & 85 years & Widow & Lives with his only daughter \\
L & Male & 84 years & Widower & Lives alone; has 2 children \\
\hline
\end{tabular}

lost, I felt disenchanted with the world in which I lived ... then I got used to it ... and today the most disgust it gives me is that I cannot do my shopping ... give me much disgust [...] I feel independent, but I am dependent ... I feel independent in my mind [...] l'm still doing some things, clinging to it, clinging to it ... but I'm doing ... subject to the consequence that everyone knows... that disturb me. (J., 81 years, widow, lives alone)

This report clearly demonstrates how the derivations of discourse enrich the narrative in terms of meaningful information for health professionals. From the view of the photograph, the elderly woman reveals in her report that the capacity to make purchases constitutes, subjectively, the limits of her independent and autonomous life, where the boundaries between youth, adulthood and old age. Independence and autonomy are thus highlighted in the discourse of this elderly woman, highlighting the importance of these capacities in determining their quality of life. The fear of falling arises in the discourse of the elderly as an element that may limit the performance of life activities and lead to immobility. Thus, there are important elements that are subjectively relevant to the elderly, which can sustain an intervention of the health professionals that favors the maintenance of mobility and prevent the worsening of the situation as the fear of falling.

The previous report is illustrative of the richness of the narrative that results from the analysis of the photographs, in the specific case of this investigation the purpose was to identify the most relevant elements for the elderly in the determination of their quality of life. Thus, the analysis was based on the registration of the discourse of the elderly about the records that were revealed to them in the sessions. The report of the elderly was transcribed and worked in order to subject it to the procedures of content analysis, following the logic inherent in the qualitative analysis, with the purpose of interpreting and reconstructing the meaning of the narrative, producing categories and propositions (explanatory hypotheses) indispensable to the understanding of the phenomena through an inductive process ${ }^{(14)}$. For the analysis, a content analysis of the narratives of the elderly was developed based on the four domains of quality of life considered in this research (physical, psychological, social relations and environment).

From the analysis of the narratives there was identification of a multiplicity of elements that stand out in the discourse of the elderly as relevant to the way they conceive their quality of life. In the first place, the references to the physical domain, namely the ability to travel and to carry out activities of daily living, are the most frequently named competences of the elderly, who proceed discursively from the analysis of the photographs:

While I can walk, do my things and be master of myself, because no one is master of myself... I'm already happy ... when someone tells me, I'll be sad ... but now they do not tell me ... I'm the one who governs me ... being old does not affect me.... (B., 84 years, widow, lives alone) 
The progressive diminution of the ability to perform activities of daily life, which were previously trivial, gives place to the awareness of the need to depend on others for their performance. Functional autonomy is a fundamental element for the maintenance of individual independence, self-determination and control over one's life. In these elderly people, freedom of action and decision-making is invariably linked to the ability to move. In this sense, the risk of compromising the quality of life in the physical domain is associated, especially to the fear of illness and immobilism:

Aging does not hurt, illness does [...] Illness is bad ... if it had not been for this, I would have been good. ... [Another elderly asks - "What happened to you?"]... I have been hospitalized there for 3 months ... to recover ... I look like a robot when I walk. (C., 81 years, widow, lives with her son and daughter-in-law)

This is so ... we do not exercise because we are trickster ... one of these days, a short time ago, the doctor... we had to do gymnastics... what we did with her we could also do very well alone, people who did not want ... I know and it's good for us, but we're trickster ... we ignore it ... we give ourselves to it and it's getting worse... I'm more trapped now, but when you see the weather is fine, I'm going there out, I sit there... now a person is always sitting here all day, this is always for worse... ( $\mathrm{H} ., 84$ years, single, lives alone)

The second domain of quality of life that stands out most in the narrative of the elderly is social relations. In most of the reports, references to a decrease in social life appear. This break in social ties associated with the aging process is also associated with difficulties in locomotion:

When I could walk, I had friends to go to their house ... now I stopped walking ... (C., 81 years, widow, lives with her son and daughter-in-law)

Grieving, in particular, and the consequent rupture of affective bonds, in many situations, has an emotional repercussion. In these cases, the break in the routine leaves a feeling of emptiness in the elderly:

Before my husband passed away... and even when he was there and I had to work hard ... I miss it! I miss him, even sick ... it was a routine that I had, a concern ... when I got up he was the first to be treated ... when he died, there was a day later, when I woke up at 8am, I woke up scared because I thought I still had not treated him ... no, I did not cry ... I lived ... and today I relive this past, but ... no pain ... I worked hard, I did a lot ... it's life ... it's sincerity... (J., 81 years, widow, lives alone)

The psychological domain of quality of life is the third domain that is evident in the discourse of the elderly, although often associated to the physical and social relations domains. In this field, the references to the feeling of loneliness and sadness are highlighted in the inability to go wherever you want. The desire to be elsewhere and to have a different condition is elements of the narrative that recurrently appear in the discourse of the elderly:

[Referring to feeling sad] to be like this one day ... and to think that I could be on the street in the sun and I having to be standing here [...] I liked being close to my sisters, but they ... they got married, they're in Lisbon only come here from time to time, and then ... the fact that they are far away has not affected me at all
... I'm here in my corner ... sometimes they come here or I go there, depending ... and how will I explain ... we just need to get together, not to be home alone ... which is what affects us a little. (A., 68 years, single, lives alone)

There are several reports in which the breaking of family ties is accompanied by resentment, the idea of abandonment and the feeling of loneliness:

I came here 3 or 4 months ago... I asked my children ... what is certain is that I have been here for a year and a half and the months have already passed ... ah ... I still have to give you the message: until when do 3 or 4 months goes by?. (E., 76 years, widow, lives alone)

Sometimes we feel alone ... the children do not care about their parents, as unfortunately it is happening ... (G., 74 years, married, lives with the partner)

Finally, in the environment surrounding the elderly the narrative is marked by reference to the changes that occurred in the home and that arise from the need to adapt the space to the limitations associated with the aging process:

If you go to my room, it does not look like my room either ... because I have to have everything arranged on the chairs, clothes... because when I get up in the morning I cannot go to the wardrobe to get the clothes ... I have to leave some on top of a chair to dress and to put on [...] Not even my kitchen looks the same ... everything is set there ... I have to have everything there in "mounds"... what I need, I have to reach out ... I sit often in a chair [...] it cost me a lot because I always had everything tidy... anyone who went there always said so I did not mind being messy and everything would be set ... everything was tidy ... (J., 81 years, widow, lives alone)

From the discourse of the elderly encouraged by the discussion around the photographs, a set of relevant elements for the elderly and that affect their quality of life was evidenced. Many of these elements, such as anxiety, hopelessness, loneliness, are relevant in the clinical context, although they do not always arise in the form of clinical complaints.

\section{DISCUSSION}

The provision of health care for the elderly should be based on cultural plurality and the specificities of their life context. This is the only way to create the conditions for structuring nursing intervention that is closer to the reality in which the elderly are inserted, fostering reflections about the need to re-mean practices, values and attitudes ${ }^{(15)}$. As reported in other investigations, the provision of adequate and comprehensive nursing care, encompassing the biological, psychosocial, cultural and spiritual aspects, depends on the ability to take into account the specific needs of the elderly ${ }^{(16)}$. The operationalization of the concept of integral care for the elderly translates into a very broad set of nursing diagnosis statements that cover, among other needs: the need to communicate; the need to learn; the need to engage in self-actualization; the need to be distracted and the need to act according to their beliefs and values ${ }^{(17)}$. The very expectations of the elderly regarding the intervention of the nurse are not 
restricted to mere technical actions ${ }^{(18)}$. In addition to the attention to the disease, the elderly hope to create ties with the nurse, in an environment of communication that allows autonomy, resolvability and accountability ${ }^{(19)}$.

In this context, it becomes necessary to use care models that recognize the particular characteristics of each elderly and foster their autonomy and active aging. In this process, the elderly-nurse interaction is fundamental for the collection of relevant data regarding the health/disease and aging process ${ }^{(18)}$. In the institutional context, the time available for communication between the elderly and the nurse is, in many situations, scarce, being restricted to the discussion of issues related to the provision of immediate care. As pointed out by other authors, the existence of opportunities for dialogue and awareness of the importance of communication guarantee a broader range of topics that allow the psychosocial needs of the elderly to be met ${ }^{(20)}$.

Photo-elicitation and the narrative associated with it have great potential in planning nursing an intervention among specific populations, particularly the elderly population, insofar as it allows access to the reference frames of individuals. Because of its characteristics, photo-elicitation proves to be an interesting resource of work in the relationship between nurse and elderly. The quality of care directed to this population depends greatly on the acquisition of communication and interaction skills that facilitate the communicational process ${ }^{(21)}$. In this sense, photoelicitation, by provoking dialogue and providing an opportunity for the elderly to develop a narrative structured around a theme, is a tool that makes the process of nursing diagnosis easier.

The visualization of photographic images involves processes of affective and cognitive nature, leading the elderly to interpret each photograph, drawing on their past experiences and their present situation. It is in the evocation of conscious and unconscious elements that lies the value of this tool. From the visualization of the photographs results a whole narrative, understood as the organization of a sequence of events in such a way that the meaning of each event is understood through its relation with the whole ${ }^{(22)}$. In the particular case of the use of photography to foster discussion and sharing in a group of elderly people, the organization and sequencing of the narrative is the result of a process of selection by the elderly of life experiences that they consider relevant. The narrative plot allows the relationship between personal connections, linking past choices and events to subsequent events, leading the narrative coherence to be based on causality established between events. Concerns in making sense, in conferring reason and in highlighting a logic establishing intelligible relations, such as those between cause and effect, are central to the narratives analyzed.

In the use of the narrative in the planning of nursing interventions, it is incumbent upon nurses to accept the reconstructions of existence present in the narrative, whether it is a reordering of sequences or whether it is a question of rearranging the narrator's own existence. It will be up to the addressee of the narrative, the nurse, through an attitude of detachment, to correct the risk of narrative drift that closes the anamnesis: The effect of detachment, allowing to gain field, authorizes a more disinterested vision than that of the 'interested'; to the inevitable subjectivity of the writer succeeds a relative objectivity ${ }^{(23)}$. A successful narrative is more than a chronological sequence of events, it also involves an evaluative dimension, crucial for the attribution of meaning ${ }^{(22)}$. The evaluative segments of the narrative are the means used by the narrator to convey how the meaning of the sequence of narrated events is to be narrated ${ }^{(24)}$. The linguistic forms that express the evaluative structure can vary in great amplitude of structures and of linguistic choices. Mere reporting is an evaluative act insofar as the events reported are precisely because they are considered deserving of being cited because of their significance or their unusual or unexpected properties ${ }^{(22)}$. Thus, the context in which the narrative is produced is of crucial importance, in particular the specificity of the situation and the set of interactions that are established between who narrates and who is narrated. It is in this interaction that the foundations are established that allow nurses to determine nursing interventions that can fully address the needs expressed by the elderly and, at the same time, aim at promoting their autonomy and referral to self-care, which will contribute to the increase of their functional capacity and consequent increase in the quality of life.

\section{Study limitations}

As limitations of the conduction of the research, the fact that it was carried out in a single institution with a method of sampling for convenience is outstanding. The sample size also made it impossible to use the saturation criterion for delimitation in the number of subjects in the study. Thus, one cannot exclude the possibility that, with more participants, other relevant aspects could have appeared other than those reported in this research.

\section{Contributions to the sector of Nursing}

Nursing appropriation of tools, such as photo-elicitation, allows enriching the nursing knowledge that seeks to care for the person in its entirety and to provide personalized care, taking the recipient of the intervention as a unique being, implicit in unconditional respect for the other.

\section{FINAL CONSIDERATIONS}

The use of photography as a pretext to trigger dialogue, in this case, between elderly and health professionals, guarantees information relevant to the planning of interventions adjusted to the real needs and expectations of the elderly. The use of photo-elicitation allows the elderly a greater control over the derivation of speech and the pertinence of the reported episodes. To this extent, it is a useful tool for the discovery of the elements considered more relevant by the elderly. Nursing planning and interventions, based on the use of methodologies of this nature, allow for the perspective of care as a whole, interconnecting and interrelating all dimensions of the concept of care. This tool, in the context of work with institutionalized elderly, assists nursing in the holistic view of the human being, which opposes a reductionist view, which treats the part. The potential of using this technique in the context of nursing intervention lies in the way it contributes to overcome a reductionist view of the care recipient. Its use on the part of the nurse allows a more holistic 
view of the human being, since he regards the individual as an active, integrated, multiple, dynamic, self-determined, and detached from the perspective that the human being views as a reactive (or even passive) being, which values the physical, linear, stable causality that manipulates, controls.

In the specific case of the report of the elderly involved in this research, it was possible to design a nursing intervention plan directed to their concrete needs. Thus, the interventions related to the physical domain were designed so as to allow the elderly to be guided on the way to deal with the changes related to the ability to travel and to carry out activities of daily living, which should always respect the habits and preferences the elderly and promote self-care. In the domais of social relations, interventions focused on the promotion of social relations and interactions, with emphasis on the importance of maintaining social contacts. In the psychological domain, the interventions aimed at promoting the self-esteem of the elderly through activities of positive reinforcement. Regarding the environmental domain, the interventions contemplated educational actions, aimed at elucidating the elderly about technical aids, adaptive equipment and space organization. In this way, the experience of using photo-elicitation with a group of elderly people allowed to verify their potential as a strategy to collect significant and relevant information for the planning of nursing interventions.

\section{REFERENCES}

1. Rodrigues FR, Pereira MLD, Amendoeira J. [Paradigmatic transitions of health and reflections in nursing as a discipline]. Rev Rede Cuid Saúde [Internet]. 2015 [cited 2017 Nov 23];9(1):1-8. Available from: http://publicacoes.unigranrio.edu.br/index.php/rcs/article/ view/2516/1281 Portuguese.

2. Monteiro AP, Curado M. [A new epistemology of nursing: a post-human care?]. Rev Enf Ref [Internet]. 2016 [cited 2017 Nov 23];IV(8):141-148. Available from: http://dx.doi.org/10.12707/RIV15069 Portuguese.

3. Chernicharo IM, Freitas FDS, Ferreira MA. [Humanization in nursing care: contribution to the discussion about the national humanization policy]. Rev Bras Enferm [Internet]. 2013 [cited 2017 Nov 23];66(4), 564-70. Available from: http://dx.doi.org/10.1590/S003471672013000400015 Portuguese.

4. Queirós PJP, Fonseca EPA, Mariz MAD, Chaves MCR, Cantarino SG. [Meanings assigned to the concept of caring]. Rev Enf Ref [Internet]. 2016 [cited 2017 Nov 23];IV(10):85-94. Available from: http://dx.doi.org/10.12707/RIV16022 Portuguese.

5. Favero L, Pagliuca LMF, Lacerda MR. Transpersonal caring in nursing: na analysis grounded in a conceptual model. Rev Esc Enferm USP [Internet]. 2013 [cited 2017 Nov 23];47(2):489-94. Available from: http://dx.doi.org/10.1590/S0080-62342013000200032

6. Hesbeen W. Qualidade em Enfermagem - Pensamento e acção na perspectiva do cuidar. Loures (PT): Lusociência - Edições Técnicas e Científicas; 2001.

7. Calha A, Monteiro F, Hilário M. A imagem fotográfica e a narrativa como recursos no planeamento de intervenções de enfermagem ao idoso. In: Costa AP, Ribeiro J, Synthia E, Souza D, editores. In: Atas do $6^{\circ}$ Congresso Ibero-Americano em Investigação Qualitativa; 2017 [cited 2017 Nov 23];(2): Jul 12-14, Salamanca, Espanha. Aveiro (PT): Ludomédia; p. 200-9. Available from: http://proceedings.ciaiq.org/index.php/ ciaiq2017/article/view/1210

8. Melleiro MM, Gualda DMR. [The pictorial ethnographic approachn for the evalution of the health and nursing service]. Texto Contexto Enferm [Internet]. 2006 [cited 2017 Nov 23];15(1):82-8. Available from: http://dx.doi.org/10.1590/S0104-07072006000100010 Portuguese.

9. Faria NGF, Peres HHC. [Analysis of scientific literature on photographic documentation of wounds in nursing]. Rev Eletr Enf [Internet]. 2009 [cited 2017 Nov 23];11(3):704-11. Available from: https://www.revistas.ufg.br/fen/article/view/47232/23148 Portuguese.

10. Reus LH, Tittoni J. [The visibility of nursing work in the surgical center through photography]. Interface Com Saude Educ [Internet]. 2012 [cited 2017 Nov 23];16(41):485-97. Available from: http://dx.doi.org/10.1590/S1414-32832012005000034 Portuguese.

11. Carvalhais M, Sousa L. [The quality of nursing home care to dependent elderly]. Saúde Soc [Internet]. 2013 [cited 2017 Nov 23];22(1):160-72. Available from: http://dx.doi.org/10.1590/S0104-12902013000100015 Portuguese.

12. Gimenes REF, Cassiani SHB. Safety in medication preparation and administration, in light of restorative health care research. Rev Min Enferm [Internet]. 2013 [cited 2017 Nov 23];17(4): 975-83. Available from: http://dx.doi.org/10.5935/1415-2762.20130070

13. Whoqol Group. The world health organization quality of life assessment (WHOQOL): development and general psychometric properties. Soc Sci Med [Internet]. 1998 [cited 2017 Nov 23];46(12):1569-85. Available from: https://doi.org/10.1016/S0277-9536(98)00009-4

14. Guerra, I. Pesquisa Qualitativa e Análise de Conteúdo: Sentidos e formas de uso. Estoril (PT): Princípia Editora; 2006.

15. Pinheiro GML, Alvarez AM, Pires DEP. [The configuration of the work of nurses in care of the elderly in the family healthcare strategy]. Ciênc Saúde Coletiva [Internet]. 2012 [cited 2017 Nov 23];17(8):2105-15. Available from: http://dx.doi.org/10.1590/S1413-81232012000800021 Portuguese.

16. Floriano LA, Azevedo RCS, Reiners AAO, Sudré MRS. Care performed by family caregivers to dependent elderly, at home, within the context of the family health strategy. Texto Contexto Enferm [Internet]. 2012 [cited 2017 Nov 23];21(3):543-8. Available from: http://dx.doi. org/10.1590/S0104-07072012000300008

17. Clares JWB, Guedes MVC, Silva LDF, Nóbrega MML, Freitas MC. Subset of nursing diagnoses for the elderly in primary health care. Rev EsC Enferm USP [Internet]. 2016 [cited 2017 Nov 23];50(2):270-6. Available from: http://dx.doi.org/10.1590/S0080-623420160000200013 
18. Silva KM, Vicente FR, Santos SMA. [Nursing consultation to the elderly in primary health care: a literature integrative review]. Rev Bras Geriatr Gerontol [Internet]. 2014 [cited 2017 Nov 23];17(3):681-7. Available from: http://dx.doi.org/10.1590/1809-9823.2014.12108 Portuguese.

19. Almeida RT, Ciosak SI. [Comunicação do idoso e equipe de saúde da família: há integralidade?] Rev Lat-Am Enferm [Internet]. 2013 [cited 2017 Nov 23];21(4):1-7. Available from: http://www.scielo.br/pdf/rlae/v21n4/pt_0104-1169-rlae-21-04-0884.pdf Portuguese.

20. Williams KN, Ilten TB, Bower H. Meeting communication needs: topics of talk in the nursing home. J Psychosoc Nurs Ment Health Serv [Internet]. 2016 [cited 2017 Nov 23];43(7):38-45. Available from: https:// www.healio.com/psychiatry/journals/jpn/2005-7-43-7/\%7Bef836895-b726-4083-aa09-fe34c552737a\%7D/ meeting-communication-needs-topics-of-talk-in-the-nursing-home\#divReadThis

21. Haugan G. Nurse-patient interaction is a resource for hope, meaning in life and self-transcendence in nursing home patients. Scand J Caring Sci [Internet]. 2014 [cited 2017 Nov 23]; 28(1):74-88. Available from: http://dx.doi.org/10.1111/scs.12028

22. Elliott J. Using narrative in social research: Qualitative and quantitative approaches. London: Sage Publications. 2005.

23. Poirier J, Clapier-Valladon S, Raybaut P. Histórias de vida: teoria e prática. Oeiras (PT): Celta Editora; 1999.

24. Linde C. Life stories: The creation of coherence. Oxford: Oxford University Press. 1993. 